These events can only leave the impression that something is being swept under the carpet. There are serious issues at stake as to whether the UN norms for the proper exercise of self-determination have been met-most dramatically in the case of the Northern Mariana Islands, which appear to be consigned to permanent colonial status. ${ }^{22}$ Whatever view one takes on the substantive issue, however, the international community has a stake in having the proper procedures of the Organization followed.

In the meantime, I submit that the powers of the Security Council and the Trusteeship Council under the trusteeship provisions of the Charter continue, not only as to Palau, but in respect of the other entities as well. In particular, the Council continues to have the power and duty to hear petitioners pursuant to Article 87 of the Charter and, as the Secretariat has pointed out in its proposed Programme Budget for the Biennium $1988-1989,{ }^{23}$ to engage in visiting missions. Article 76 of the Charter speaks of progressive development towards self-government. The present statuses in the various parts of the territory do represent development; ${ }^{24}$ they do not represent sufficient development to constitute grounds for terminating the trust-and the definitive steps to do so have not yet been taken in spite of the President's proclamation.

ROGER S. CLARK*

\title{
ASIL AWARD TO THEODOR MERoN
}

The American Society of International Law has awarded its Certificate of Merit for 1986 to Professor Theodor Meron for his book Human Rights Law-Making in the United Nations: A Critique of Instruments and Process. The certificate is awarded annually for a "preeminent contribution to creative scholarship." Professor Meron, a member of the AJIL Board of Editors, singled out three United Nations instruments for intensive scrutiny: the International Convention on the Elimination of All Forms of Racial Discrimination, the Convention on the Elimination of All Forms of Discrimination Against Women, and the International Covenant on Civil and Political Rights. The book also subjects to critical analysis the normative and jurisdictional relations between human rights instruments and organs and discusses reforms of UN human rights lawmaking.

\footnotetext{
${ }^{22}$ See Clark, Self determination and Free Association-Should the United Nations Terminate the Pacific Islands Trust?, 21 HARV. INT'L L.J. 1 (1980); Rodriguez Orellana, In Contemplation of Micronesia: The Prospects for the Decolonization of Puerto Rico under International Law, 8 U. MiAMI INTER-AM. L. Rev. 458 (1987). But see Hills, Compact of Free Association and Micronesia: Constitutional and International Law Issues, 18 INT'L LAw. 583, 602-06 (1984). And note the dispute between the Marianas and the United States over what their deal is. See note 6 supra. Marianas officials obviously see an active, continuing role for the United Nations in this matter.

${ }^{29}$ UN Doc. A/42/6, sec. 3 , at 14 (1987).

24 Thus, at their May 1987 meeting, the states of the South Pacific Forum decided to admit the Federated States and the Marshall Islands as full members of the Forum. Some members of the Forum that agreed with this decision nonetheless expressed the view that the trusteeship is still in force. The Forum has always regarded itself as flexible on membership matters, being able to accommodate the Cook Islands and Niue, states in free association with New Zealand, albeit a different form of free association from that involving the new Micronesian entities. It is likewise able to accommodate the less than completely sovereign Federated States and Marshalls.

* Distinguished Professor of Law, Rutgers University, Camden.
} 